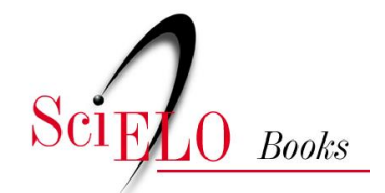

\title{
Alberto Passos Guimarães e a Revolução Agrária não camponesa
}

\author{
Raimundo Santos
}

SANTOS, R. Agraristas políticos brasileiros [online]. Rio de Janeiro: Centro Edelstein de Pesquisas Sociais, 2008. pp. 34-73. Alberto Passos Guimarães e a Revolução Agrária não camponesa. ISBN: 978-85-99662-81-6. Available from SciELO Books $<$ http://books.scielo.org $>$.

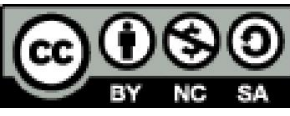

All the contents of this chapter, except where otherwise noted, is licensed under a Creative Commons Attribution-Non Commercial-ShareAlike 3.0 Unported.

Todo o conteúdo deste capítulo, exceto quando houver ressalva, é publicado sob a licença Creative Commons Atribuição Uso Não Comercial - Partilha nos Mesmos Termos 3.0 Não adaptada.

Todo el contenido de este capítulo, excepto donde se indique lo contrario, está bajo licencia de la licencia Creative Commons Reconocimento-NoComercial-CompartirIgual 3.0 Unported. 


\section{Alberto Passos Guimarães e a Revolução Agrária Não CAMPonesA ${ }^{40}$}

Quando se examina a publicística brasileira, observam-se várias referências ao nexo feudalidade-prussianismo com que Lênin caracterizou a formação social russa com fins revolucionários. Por muito tempo alguns autores pecebistas chamaram-nos a atenção por divisarem traços prussianos em nossa modernização, particularmente Nelson Werneck Sodré, no seu livro de 1962 e Ivan Ribeiro, autor que também recorre ao conceito leniniano ao se referir à agricultura do tempo mais contemporâneo (Ribeiro, 1975). Não centralizávamos no nexo leniniano o eixo do pensamento comunista que em meados dos anos 1950 começa a firmar seu compromisso com a democracia política (Santos, 1996). No entanto, já tínhamos registrado a presença da hipótese prussiana em outros intelectuais da geração de Ivan Ribeiro que, como este, buscam conferir alcance estratégico à política de resistência democrática ao regime de 1964. Eles tentam assentar esta valorização da democracia representativa em uma nova visão da nossa modernização (ver, por exemplo, Konder, 1980; Vianna, 1976, especialmente 1981). Quanto ao conceito de feudalismo, então observávamos que o seu uso tinha em Sodré e em Passos Guimarães um sentido instrumental. Em tal acepção - de "residualidade feudalista" contemporânea -, esta noção segundo a fórmula leniniana também adquire relevância no comunismo brasileiro. Neste texto sugerimos que o nexo feudalidade-prussianismo serve de ponto de referência a áreas comunistas que, nos tempos das inteligentsias imaginativas, como a do ISEB, começaram a indagar como seria o caminho brasileiro ao socialismo.

Só viemos a nos deter em Alberto Passos Guimarães como ensaísta dessa raiz quando melhor atentamos para o fato de que, no seu registro da questão dos "restos feudais", o autor de Quatro séculos de latifúndio (1963) igualmente menciona o outro termo da fórmula leniniana. Nesta ocasião mais recente, relíamos o ensaísta, indispostos com a bibliografia que o confina na pobreza teórica justamente por recorrer à hipótese feudalista. Este sumário juízo não permite averiguar se Passos Guimarães não se assemelha a outros

\footnotetext{
40 Primeira parte do texto "Venturas e desventuras da revolução camponesa no Brasil" (Relatório parcial da pesquisa "Pensamento social e agrarismo no Brasil", CPDA/UFRRJ, outubro de 2007).
} 
autores cujas referências ao feudalismo não embotam suas imagens de Brasil, como Euclides da Cunha, Gilberto Freyre e Raimundo Faoro, por exemplo. Logo passamos a ver que a remissão àquele leninismo fazia de Passos Guimarães um publicista que não se restringia ao tema agrário. Favorecia este ponto os indícios que mostram ter ele influído na Declaração de Março de 1958; como se sabido, a resolução que encerrara no PCB a controvérsia sobre o stalinismo (1956-57) e fixa a "nova política", como é conhecida a virada na orientação dos comunistas dessa época.

Os autores que em diferentes momentos recorrem à hipótese prussiana não buscam apenas compreender o mundo agrário. Os publicistas do tempo da Declaração de Março, ainda sem suficiente clareza, defrontamse com consequências que lhes traz o uso do conceito. Por um lado, passam a ver outras dimensões na imagem de Brasil que possuíam e, por outro, a calibrar a estratégia do seu partido conforme a associação entre modernização conservadora e democracia política sugerida por aquele leninismo político. Eram, assim, levados a colocar seus fins de largo alcance a partir das ações do curto e médio termos, ou seja, pensar o agir revolucionário em função do reformismo democrático de frente única permanente, direção à qual os comunistas já vinham caminhando. Mesmo que o conjunto do partido não discernisse com muita precisão aonde iam os próprios passos e grande parte do seu núcleo dirigente negasse passagem a um aprofundamento do rumo renovador que tomaram.

Tendo esse pano de fundo, teceremos nestas páginas considerações sobre os seguintes pontos: a) sem partir de uma interpretação de Brasil que fundamentasse a revolução, dela, no entanto, Passos Guimarães esboça traços que o diferenciam de certas áreas pecebistas; b) sem chegar a uma teoria de revolução, o ensaísta pensa em uma "revolução nacional" por meio da luta de classes no mundo das mediações; no qual os protagonistas são convocados a incidir de modo efetivo; c) a publicística de Alberto Passos Guimarães se orienta para o domínio da conjuntura que então vivia o PCB; terreno no qual o ator é chamado a definir tarefas; e d) as especificidades da "revolução nacional" levam o autor a redimensionar o tipo de interpelação dos grupos agrários, lastreando aquela nova mediação à época já posta em prática pelos comunistas. $\mathrm{O}$ presente ensaio consiste numa recensão de alguns textos que Alberto Passos Guimarães dirige a seu partido, almejando o autor destas notas que, desde tal lugar militante, essa releitura do publicista avive traços do perfil do $\mathrm{PCB}$, inclusive das suas não poucas aporias, aliás, presentes ainda hoje em ambientes de outras esquerdas que se formaram bem depois daqueles tempos.

Concentramos a atenção nos artigos que Alberto Passos Guimarães escreve para os debates do V Congresso de 1960 e algumas vezes nos reportamos a Quatro séculos de latifúndio. Relevamos o congresso que reafirma a virada de 1958 e os textos nos quais o ensaísta busca delimitar para seu partido o campo do tempo real no qual os comunistas, segundo ele, haveriam de potenciar sua ação político-articulatória. Quanto ao seu excurso sobre a revolução agrária, sublinhamos o tema da interpelação camponesa a já nos referimos como de tipo sindical-camponês (Santos, 2002). Esperamos, ao final destas notas, deixar sugerido que com sua ideia de mediação Passos Guimarães antecipa pontos de um equacionamento do "problema camponês" que terá continuidade na matriz comunista. Referimo-nos aos ensaios com os quais Ivan Ribeiro retoma a questão agrária a partir dos temas da modernização conservadora da agricultura e da nova diversidade camponesa no pós-64. Agora numa versão, por assim dizer, mais secularizada ainda, os protagonistas da interpelação dos agrários sendo referidos mais decididamente tanto à política como tal quanto ao tempo permanente das "medidas parciais de reforma agrária", como se dizia à época, ou, como estamos dizendo de alguns anos para cá, das "políticas públicas" as mais variadas dirigidas à reforma do mundo rural.

\section{As possibilidades da revolução reformista}

A rigor, Alberto Passos Guimarães se vale da teoria leniniana da revolução na periferia capitalista e dela nos traz não apenas o velho tema da relação entre reforma e revolução. O autor leva-nos a revisitar questões e controvérsias de um distante mundo pecebista expressivas do estilo de pensar e agir da esquerda histórica. São traços relativos a certos tipos de requerimentos, a saber: a) descortinado o campo de ação, como já aludido, o ator revolucionário é chamado a operar de modo efetivo; e b) ao batalhar por "reformas estruturais", dele também se exige que mostre "soluções positivas"; e c) concretizadas algumas "soluções positivas", espera-se que ele valorize seus resultados (longe do "quanto pior, melhor"); postura que favorece tanto a continuidade das mudanças quanto pensar em eventuais ajustes na tática do curto prazo. 
À época da virada de 1958, Armênio Guedes foi um dos comunistas a registrar que a melhora no pensamento pecebista trazida pela Declaração de Março requeria projetar os objetivos mais próximos na questão geral da democratização do país. Nada consensual (muito menos naquele tempo), esta clássica controvérsia sobre reforma e revolução vem se apresentar sob a forma de uma discussão muito mal compreendida entre nós: a questão das etapas. No entanto, no PCB, a distinção entre a então chamada "etapa atual" da revolução brasileira e o futuro socialista torna-se questão definidora. Por aí passavam as possibilidades de um protagonismo que militasse a favor de uma revolução reformista no Brasil. Isto é, um protagonismo dependente da postura realista e lúcida do ator revolucionário ante a política realmente existente; ponto que à época repartia as esquerdas, em particular os comunistas, então também muito envolvidos na disputa pela posse da identidade doutrinária.

Diversamente da virada de 1958, parece não ter Alberto Passos Guimarães participado de forma importante na preparação das teses com as quais o Comitê Central do PCB convocou o V Congresso, embora seja um dos principais defensores da "nova política" na Tribuna de debates do evento. Nisso convergia com outros círculos pecebistas que então buscavam uma via política ao socialismo no Brasil (por exemplo, Chaves Neto, 1955, e Coelho, 1960), alguns publicistas aludindo ao caminho democrático ao socialismo de que falavam os comunistas italianos desde o XX Congresso do Partido Comunista da União Soviética (1956), tendo Palmiro Togriatti alguns textos seus publicados na imprensa pecebista dessa época.

No primeiro artigo dirigido ao V Congresso, "A questão das etapas da revolução brasileira", Alberto Passos Guimarães argumenta que a revolução de "libertação nacional" - num país como o Brasil - não se reduzia a este modelo oriundo do movimento comunista internacional. Ao se referir ao cenário prescrito pela III Internacional Comunista (IC) para os países coloniais e dependentes, Passos Guimarães faz uma primeira qualificação. Leva ao V Congresso a polêmica que Lênin sustentara contra os marxistas ortodoxos que insistiam na inevitabilidade de uma revolução burguesa na Rússia do início do século XX conduzida por um grupo econômico ao modo clássico. O líder bolchevique dizia que, desde meados do século XIX, a Rússia trilhava rota junker-conservadora. No entanto, ainda havia oportunidade para uma variante em moldes "democráticoburgueses", caso à frente dela se pusessem grupos sociais de outro tipo.
Esta abertura com que Lênin pensara o caso dos países que, como a Rússia, chegavam atrasados ao moderno arrastando um vasto mundo camponês, também era útil entre nós, qualificada a circunstância brasileira pela dependência. Com a mesma linguagem das Teses, Alberto Passos Guimarães fala de uma revolução igualmente em duas etapas - numa primeira, levada a cabo pela burguesia e noutra (fase de transformações propriamente anti-imperialistas e antifeudais) sob liderança do proletariado (Passos Guimarães, 1960a).

Ao invocar aquela proposição de Lênin $^{41}$, o autor visa singularizar uma "revolução nacional" já com certo desenvolvimento capitalista, o que nos diferenciava de outras nações coloniais e dependentes. Colocando o Brasil no modelo leniniano, também se podia pensar nossa modernização por caminhos não clássicos. De um tipo - retomava ele aquele leninismo - se a dirigisse grupos burgueses débeis coligados com velhos estratos pró-imperialistas e pré-capitalistas ou, de outro, caso se formasse uma aliança entre componentes burgueses interessados no desenvolvimento e agrupamentos reformistas influentes. Diz Passos Guimarães que no Brasil já chamava a atenção a presença de forças populares no movimento (burguês) de emancipação nacional que ganhara ímpeto nas cidades após o suicídio de Vargas (idem). Ao referir o modelo nacional libertador ao registro composto por Lênin para o capitalismo periférico, o ensaísta realçava traços especiais da revolução no Brasil, atento, como o PCB, à dinâmica daqueles animados anos nacionaldesenvolvimentistas e cepalinos.

Alberto Passos Guimarães repõe no V Congresso temas das próprias Teses oficiais sob registro que o diferencia em vários pontos. Assim, a questão das etapas não se subsumia a uma disputa doutrinária, sendo tema que conferia sentido aos movimentos do ator revolucionário. O publicista não

\footnotetext{
${ }^{41}$ O tema da "frente única" aparece na Declaração de Março como verdadeiro lema, a saber: "Nenhuma classe ou camada social, isoladamente, pode vencer as resistências das forças interessadas na conservação da dependência do país aos monopólios ianques e na manutenção do monopólio da terra. A experiência da vida política brasileira tem demonstrado que as vitórias anti-imperialistas e democráticas parciais só puderam ser obtidas pela atuação em frente única de várias forças interessadas na emancipação e no progresso do país. A aliança destas forças resulta, portanto, de uma exigência da própria situação objetiva" (PCB, 1960: 61). Num tópico chamado: "As classes sociais, o Estado e as instituições do Brasil", há sugestiva enumeração dos componentes da "sociedade civil" que comporiam a frente única.
} 
só busca desconstruir o radicalismo remanescente dos anos da Guerra Fria contra o qual viera a Declaração de Março -, como tenta divisar uma estratégia (a "arte" da política, como repete várias vezes, usando expressão de Lênin) que levasse os comunistas a incidir na conjuntura realmente existente naquela época. Tratava-se de dotar o agir no tempo presente de habilidades que favorecessem a diretriz das mudanças graduais e da formação dos (sucessivos) governos reformistas; terrenos estes - reformas e esfera estatal nos quais o ator operaria de modo construtivo com cálculo estratégico.

Como veremos adiante, o publicista também argumenta a favor do chamado caminho pacífico da revolução brasileira, uma das principais teses aprovada no V Congresso. Desde o suicídio de Getúlio, o PCB percebia que teria mais gravitação à medida que seguisse "normal" o curso dos acontecimentos sob o regime da Constituição de 1946. Por esse lado do problema, a questão agrária viria a adquirir outro significado no pensamento pecebista. Passos Guimarães aporta uma ideia de revolução agrária que atribuía ao "movimento camponês" papel diverso da função revolucionária stricto sensu definida no modelo da revolução democráticoburguesa. Este ponto do "papel dos camponeses na revolução" será controverso no V Congresso. Algumas áreas comunistas reagiram à minimização da importância dos agrários na frente única devido ao maior realce que, segundo diziam, tanto a Declaração de Março quanto as Teses conferiam à burguesia nacional. Alberto Passos Guimarães põe a questão em conformidade com a seguinte marca da circunstância nacional: o fato de termos entre nós um campesinato muito débil, como já anotara a Declaração de Março. ${ }^{42} \mathrm{Ou}$, dito de um modo mais geral: no Brasil, a revolução burguesa seria um processo sem a presença forte das classes que perfilavam os modelos revolucionários de Marx (a burguesia e proletariado) e de Lênin (um campesinato rebelde).

Logo voltaremos àquele primeiro artigo de Alberto Passos Guimarães e ao tema do curso "normal" dos acontecimentos. Vejamos agora o texto "Uma falsificação e vários erros crassos na questão das etapas", num ponto em que o autor responde aos seus críticos pelo modo "direitista" como trouxera ao congresso (diziam alguns deles na Tribuna de debates) a discussão sobre as etapas e deixemos o seu tópico agrário para mais adiante.

\footnotetext{
42 Recorde-se que o texto de 1958 dizia que o "movimento camponês" brasileiro era
} "bastante atrasado, sendo baixíssimo o seu nível de organização" (PCB, 1958; 1982).
Neste texto, o publicista centraliza sua polêmica na ambiguidade que havia sido introduzida nas "Teses". Ele a chama de "duas estratégias numa só etapa da revolução" e atenta para a indefinição que ela trazia ao ator ante sua circunstância mais próxima. Passos Guimarães se refere à dubiedade dessa questão da passagem do governo nacionalista e democrático (governo de frente única construído "nos quadros do regime vigente", hegemonizado pela burguesia e correspondente a toda uma etapa "histórica e estratégica") para o poder das forças anti-imperialistas e antifeudais "sob direção do proletariado" (Passos Guimarães, 1960b). Segundo o autor, as Teses haviam esboçado o problema das etapas "mas não o enfrentam(vam)" claramente. Diferenciadas aquelas etapas, as Teses, no entanto, tratavam dos objetivos e tarefas relativas a seus tipos de poder - aqui o ponto - como se se referissem a uma única fase. Essa era a aporia contida na referência das Teses à revolução brasileira como uma revolução "na atual etapa" (o tempo corrente e o futuro mais ou menos próximo) "anti-imperialista e antifeudal, nacional e democrática". Este complemento "nacional e democrática" diluía a função do governo nacionalista e democrático, repitase os termos daquela discussão, alcançado nos marcos do capitalismo.

O cotejo não era ocioso, quando se pensa que à época a "gramática" marxista-leninista marcava a ação militante. Passos Guimarães vê a revolução como um curso progressivo, inteligível justamente a partir da distinção cronológica. Reduzir as etapas a uma só constituía passo formulativo que levava o ator a desconhecer o mundo efetivo disposto à sua frente. Destituído de baliza, lançava-se a combate em chão incerto. "Sem estratégia", agiria sob influência de um futuro extraído de uma imaginária segunda etapa sob a ditadura proletária. O protagonista passava a guiar-se por uma problematização puramente abstrata da revolução. Daí a questão da etapa tornar-se decisiva: obrigava o PCB a enfrentar o "teste da revolução nacional" (sic). Aqui estava o calcanhar de Aquiles, o papel "turnessol", nas palavras de Passos Guimarães, que diferenciava os revolucionários ante o dilema que ameaçava "aprisionar" as Teses: ou aceitar a revolução nacional tout court, isto é, como uma revolução "que não vá além da emancipação burguesa da dominação imperialista (coisa à época, diz o autor, impossível sem o apoio do movimento democrático em que se inclui o proletariado)"; ou negar-lhe importância conquanto já não teria ela tempo para realizar transformações burguesas progressistas em moldes democráticos. 
O ponto consistia em conferir dimensão revolucionária ao que Alberto Passos Guimarães chamava de "período intermediário" e vislumbrar (em cores ainda doutrinais) o campo da luta política. O autor põe as esquerdas diante da questão mais geral do nosso capitalismo tardio: seguir rumo prussiano ou democrático conforme o tipo de atores à frente da modernização. Mas o argumento de Lênin também viria conferir sentido prático à "estratégia", ao agir no curto e médio prazos. A "etapa atual" da revolução, vale repetir, a hora a que o ator revolucionário é chamado a operar "e que é, queiram ou não os radicalistas da extrema ou da meia 'esquerda', uma etapa que corresponde a um período anterior ao da forma inicial da ditadura do proletariado, isto é, anterior à forma do poder das forças anti-imperialistas e antifeudais", diz o autor, usando linguagem marxista-leninista, mas se referindo a um futuro mais ou menos próximo (Passos Guimarães, 1960b).

Em "Uma falsificação e vários erros crassos na questão das etapas", Alberto Passos Guimarães exige que fosse esclarecida a questão do trânsito do governo nacional e democrático (no regime capitalista) ao governo do novo poder da etapa subsequente (idem) divisado na doutrina. O primeiro ponto seria registrar que o "governo nacional e democrático", de caráter burguês, desenvolver-se-ia abrindo caminho ao avanço da revolução brasileira em toda sua extensão até a fase anti-imperialista e antifeudal (idem). No caso dos articulistas com os quais polemizava no V Congresso ("esquerdistas", como os chama), essa questão de não se ter "estratégia" (diz o autor a propósito do que eles pensavam por trás daquela indefinição) aparecia no recurso que lançavam mão para se referirem à questão da etapa: o conceito clássico de etapa revolucionária. Isto é, tomavam-no no "sentido largo" de uma etapa marcada "por transformações qualitativas na base econômica (substituição de velhas relações de produção por outras novas) e na natureza de classe do poder político (substituição de classes no poder)" (idem). Passos Guimarães observa que tais articulistas recorriam ao mesmo conceito (como, aliás, lembra ainda, havia escrito o principal deles, Jacob Gorender, na Tribuna de debates do congresso) que usam os historiadores quando falam de grandes períodos. O desafio posto ao protagonista, no entanto, era divisar o teatro efetivo no qual se feria a luta na conjuntura precisa. Indo o ponto, diz Passos Guimarães: "Mas em política prática, o conceito para periodizar de antemão, para determinar a previsão estratégica, para delimitar as etapas históricas ou estratégicas, é o conceito stricto sensu de mudança na superestrutura, de mudanças nas instituições políticas, na composição de classe do poder, mudanças que são a condição política preliminar para as ulteriores transformações na base econômica, nas relações de produção" (idem). Não haveria, assim, porque a periodização dos acontecimentos e a delimitação das etapas ser tarefa exclusiva dos historiadores conquanto, neste caso, "que papel estaria reservado à estratégia política? quê seria da definição leninista da política como 'arte?", (idem), repete Passos Guimarães, citando seu autor preferido e precisando o ponto da incidência do ator no tempo presente e real.

\section{O tempo no socialismo brasileiro}

Desde o primeiro artigo, o sentido do argumento de Alberto Passos Guimarães consistia em afirmar no V Congresso, contra os "esquerdistas" (em meio "ao seu torneio de doutrinarismo"), a função da "estratégia política", a necessidade de o protagonista dispor de rota firme e segura. O autor reclama da ambiguidade quanto à "revolução nacional" (vê-la como revolução consumada ou negar-lhe valor) e lembra que os avanços da Declaração de Março e das Teses (na "interpretação dos fenômenos peculiares ao nosso país") haviam levado o PCB a um "problema novo" ainda obscuro na "nova política", qual seja, o de delimitar a "ordem de grandeza e a ordem de sucessão, no espaço e no tempo, das tarefas correspondentes à revolução brasileira, isto é, da revolução anti-imperialista e antifeudal" (Passos Guimarães, 1960a). Em vez de banalizá-lo, mesmo usando linguagem antiga, Alberto Passos Guimarães vê nesse tema "o mais complexo e o mais importante dos problemas a enfrentar para se trilhar o caminho brasileiro ao socialismo" (idem). O autor queria afastar a propensão à duplicidade de estratégias - compulsão, aliás, de grande aderência na cultura revolucionária -; ambiguidade que, repita-se o autor e os termos daquela discussão congressual, induzia a se pensar que somente sob um governo como o da segunda etapa da revolução é que adviriam as verdadeiras mudanças (idem); nesta hipótese, o protagonista desconhecendo o tempo real como lugar de um agir efetivo e construtivo. 
Divisar o caso brasileiro à luz dos textos de Lênin sobre a Revolução russa de 1905 significava grande abertura analítica. ${ }^{43}$ Todavia, para pensar a práxis do curto termo, Alberto Passos Guimarães avaliava o valor das mudanças que haveriam de processar-se na primeira fase da revolução conforme se destinassem a manter ou destruir a "velha ordem de coisas" (cf. Lênin). Citemos o autor: "Em relação às tarefas da revolução antiimperialista, podem considerar-se revolucionárias todas as transformações burguesas (sejam simples reformas ou mudanças profundas) que simultaneamente resultem na destruição dos laços com o imperialismo e expressem um tipo de desenvolvimento independente baseado no capitalismo de Estado e no capital privado nacional. Em relação às tarefas da revolução antifeudal, podem considerar-se revolucionárias as transformações burguesas, sejam reformas ou mudanças profundas, que simultaneamente resultem na destruição dos laços com o feudalismo, na destruição das relações pré-capitalistas e expressem um tipo de desenvolvimento democrático baseado no capitalismo de Estado e na propriedade camponesa" (idem). Fica aí sugerido que nossa modalidade de revolução pressupunha uma ideia de complementaridade das mudanças que haveriam de se concretizar sob diferentes graus e em tempo continuado.

Colocar o cenário de uma revolução burguesa democrática não só trazia o tema das coligações e da hegemonia como atribuía função decisiva à conduta do ator. Caso agisse segundo um plano ou estratégia e visasse metas com "firmeza" e "segurança", o processo poderia desdobrar-se até chegar ao novo tipo de governo e de poder. É sob esse registro de uma revolução progressiva por etapas que Alberto Passos Guimarães delineia o "caminho brasileiro ao socialismo". Para ele, quanto mais clara a delimitação das duas etapas e das tarefas relativas a cada uma delas, mais se distinguiria no processo anti-imperialista e antifeudal - este largo período

\footnotetext{
${ }^{43}$ Leia-se a referência de Passos Guimarães "No Brasil de nossos dias o problema do caráter das transformações de nossa sociedade só pode ser equacionado nos termos que Lênin o colocava. Não há nas presentes condições brasileiras um curso apenas, um caminho apenas para o desenvolvimento do capitalismo mas dois cursos ou dois caminhos: o reformista, seguido pela parte conciliadora da burguesia, é o da acomodação, da associação ou da subordinação ao imperialismo e aos restos do feudalismo" (Passos Guimarães,1960a). O autor não deixa evidente a associação desse tema à questão democrática no sentido que se conhece em outros autores pecebistas. Observe-se ainda que Passos Guimarães usa o termo reformista na mesma acepção que aparece no opúsculo leniniano de 1907, como sinônimo de conservador (idem)
}

que o autor divisava na "revolução nacional" - "as fases evolutivas de desenvolvimento gradual que se realizam dentro de cada etapa e os saltos ou transformações radicais que marcariam a passagem de uma para outra etapa, entre as simples mudanças na correlação de forças que correspondem às fases de uma mesma etapa histórica e as mudanças na correlação de classes (substituição de classes no poder) que correspondem à passagem a uma nova etapa histórica" (idem).

Sob formalização marxista-leninista, Alberto Passos Guimarães reivindica nos seus textos a tarefa de prosseguir com a "correta compreensão" do caminho brasileiro iniciada com a Declaração de Março.

É certo que ainda compartilha o velho "objetivo final" da conquista sob hegemonia do proletariado - de um novo poder anti-imperialista e antifeudal que transite até o socialismo. ${ }^{44}$ Note-se, contudo, o empenho do autor em perquirir nossas peculiaridades justamente pondo atenção neste ponto da projeção dos primeiros tempos do caminho brasileiro ao socialismo. Citemo-lo de novo na questão decisiva: o inevitável "período intermediário" que ia da conjuntura que então se vivia a um futuro próximo e ao regime "a que se deverá chegar após esse período intermediário, ou seja, o poder das forças anti-imperialistas e antifeudais" (idem). Passos Guimarães traduzia para um tempo mais ou menos próximo o cálculo estratégico alimentado pela doutrina, tentando divisar um momento (do "período intermediário") como um mundo real e já tangível ao redor daquele ano 1960, tempo marcado por movidas variações da conjuntura.

Essa é a questão real que não recebera tratamento "com toda a indispensável minudência, a fim de que possamos divisar - diz o autor claramente a natureza, a profundidade e a extensão das mudanças que durante ele deverão verificar-se a partir do atual regime político até sua substituição por um novo regime" (idem). No plano da política, no qual o ator revolucionário tem vida pública, tratava-se de responder à indagação de se nesse período poderia ocorrer uma recomposição do Estado "com a saída de

${ }^{44}$ Leia-se no autor: "Diga-se de passagem que o tipo de poder das forças anti-imperialistas e antifeudais proposta como objetivo final nas Teses não difere, quanto ao seu conteúdo do tipo de poder proposto como objetivo final no Programa de 1954 (governo democrático popular ou ditadura das forças antifeudais e anti-imperialistas) a não ser pela precedência que é dada no último às forças antifeudais. Ambos pressupõem no entanto, um traço essencial comum - a hegemonia do proletariado" (idem) 
umas e a entradas de outras classes e camadas sociais" (idem). Citemos sua formalização: "A resposta a esta pergunta exige que ampliemos, e aprofundemos, os nossos conhecimentos a respeito das seguintes questões: 1) quais as classes e camadas que participam, atualmente, do poder; 2) quais as classes e camadas que na atual etapa ou num futuro imediato poderão ser desalojadas do poder; 3) quais as classes e camadas que, na atual etapa ou num futuro imediato substituirão as camadas que serão desalojadas e 4) qual a classe que agora detém a hegemonia e qual a classe às mãos da qual passará na atual etapa ou num futuro imediato a hegemonia política" (idem). É assim que o autor, usando esquema classista, centraliza na recomposição do Estado sua controvérsia sobre a revolução em tanto problemática do presente - ao tempo que também descrevia no processo revolucionário alterações seguindo a sequiência que aparece nos textos da "nova política": governo, regime e estado. ${ }^{45}$ Apenas à primeira daquelas indagações as Teses ofereciam resposta, diz Alberto Passos Guimarães citando a tese 18: "Atualmente o Estado brasileiro representa os interesses dos latifundiários, dos setores capitalistas ligados ao imperialismo (comerciantes, industriais associados a capitais monopolistas estrangeiros) particularmente norte-americano e também da burguesia interessada no desenvolvimento independente da economia nacional" (Passos Guimarães, 1960a). No entanto, acrescentava ele, no raciocínio desenvolvido em outras proposições, as Teses não resolviam a questão maior do curso da revolução burguesa. Citemo-lo no texto ora comentado, na passagem em que o autor volta a relevar o ponto subentendido nas Teses: o de que em todo o processo da revolução anti-imperialista e antifeudal "só haverá um desenlace no momento em que o poder passará das mãos dos latifundiários, dos setores capitalistas ligados ao imperialismo, particularmente o norte-americano e também da burguesia interessada no

\footnotetext{
${ }^{45}$ A propósito da questão do Estado, observe-se que as Teses repetiam este trecho que abre o tópico da Declaração de Março de nome "A democratização da vida política nacional": "O desenvolvimento capitalista do país não podia deixar de refletir-se no caráter do Estado brasileiro, em seu regime político e na composição do governo" (PCB, 1958; 1982: 8). O tema volta num tópico das Teses sugestivamente chamado: "As classes sociais, o Estado e as instituições do Brasil". Não se tem até aqui registro da origem dessas referências (ao modo de $O$ dezoito brumário). Esse ponto sobre o caráter do Estado brasileiro reaparece na caracterização do regime de 1964 que o Informe de Balanço ao VI Congresso de 1967 faz em um tópico chamado "A mudança do regime político", onde se lê que o golpe militar não havia sido simples mudança de governo, mas "modificou profundamente a forma estatal de poder, com danos incontáveis para os interesses da maioria do povo e do conjunto da nação" (PCB, 1967; 1980). (Grifos do autor destas notas).
}

desenvolvimento da economia nacional diretamente às "forças antiimperialistas e antifeudais" (idem).

Posto esse cenário mais distante nas Teses, o "período intermediário" figuraria como um "mero interregno durante o qual nenhuma classe ou camada cederá o lugar a nenhuma classe ou camada, embora possa haver um governo ou uma sucessão de governos com nuanças políticas pouco demarcadas" (idem). Passos Guimarães exige que se dissesse que, antes da passagem a um novo regime das forças anti-imperialistas e antifeudais (o futuro incerto da doutrina), "as condições estarão dadas para outras modificações na composição do Estado brasileiro" (idem). O "período intermediário" constituía-se em uma "etapa histórica", "específica" da revolução brasileira. ${ }^{46}$ Alberto Passos Guimarães completa esta questão da fase intermediária ("representada pela mudança no poder de determinadas classes e camadas") retornando ao tema do processo da revolução antiimperialista e antifeudal como um período que, diz ele, "segundo posso entender, desdobra-se em duas etapas: a etapa nacional e democrática e a etapa democrático-popular" (grifos nossos). Mesmo ao modo antigo, o autor recortava tema vivo e de interesse prático para aquela fase do pré-64 na qual os comunistas e as demais esquerdas tinham de atuar ao dia, se quisessem manter seu horizonte doutrinário (no caso, "a etapa democrático-popular") com algum contato com a realidade efetiva posta diante deles. Ademais, lembre-se que o publicista via a intervenção do ator de orientação marxistaleninista em termos de uma estratégia ou "arte" da política (Lênin).

Vê-se quão difícil era para Alberto Passos Guimarães converter a lucidez que o PCB obtinha a cada dia numa compreensão do agir para o

${ }^{46}$ Aquele ponto lembra a questão das vias ao socialismo, a propósito da qual, em seu texto Crítica ao Programa de Erfurt, Engels dizia: "Uma coisa absolutamente certa é que nosso Partido e a classe operária não podem chegar a dominação senão sob a forma da república democrática. Esta última inclusive é a forma específica da ditadura do proletariado, como já o demonstrou a Grande Revolução Francesa" (Engels, 1891; 1973). Recorde-se que Engels conhecera os resultados das revoluções econômicas "pelo alto" (expressão dele) subsequentes à derrota das revoluções europeias de 1848. Engels tem outras passagens sugestivas, o prussianismo estando presente nas suas últimas reflexões ("Introdução" a As lutas de classes na França de 1848 a 1850) sobre o método democrático ao socialismo (Engels, 1895; 1977). No entanto, é Sodré o autor brasileiro da época (Sodré, 1962) mais próximo dessa referência na qual Engels associa ao padrão prussiano da modernização a valorização da democracia no contexto de avanço progressivo da social-democracia alemã no final do século XIX. (Ver, especialmente, Engels, 1891; 1973). 
curto e o médio prazos consultando os objetivos doutrinários. Com efeito, nos últimos tópicos do texto sobre as etapas, o autor retoma a fala nova permeada pelo marxismo-leninismo. Voltando aquele tema das etapas (que não seriam estanques, tarefas de uma passando para outro tempo), Passos Guimarães diz que as diferenciava, por um lado, com base no deslocamento de classes e camadas no poder (na primeira etapa, saída das classes mais atrasadas e ligadas ao neocolonialismo; na segunda, a de grupos capitalistas vinculados ao imperialismo, os latifundiários burguesas e outras camadas mais reacionárias); e, por outro, que também distinguia as etapas conforme as tarefas programáticas (na primeira etapa, medidas para deter o imperialismo e impulsionar a revolução agrária que "não passará de uma reforma agrária inicial (e ainda não camponesa) que varra os vestígios caducos do escravismo e do feudalismo"; e numa segunda, tarefas visando extinguir a dependência e a "instituição de uma reforma agrária radical" de tipo camponês "que transformará por completo a estrutura agrária" (Passos Guimarães, 1960a). Voltaremos a este ponto agrário no próximo tópico, apresentando-o como uma argumentação que distingue o publicista.

É possível afirmar que há naquele tipo de revolução descrito por Alberto Passos Guimarães uma visão não rupturista. Suas ideias sobre o "período intermediário" e a sucessão das etapas diziam muito do sentido progressivo da nova política: "Assim como no curso da primeira etapa poderá haver fases táticas diversas, como modificações de grau na composição dos governos de caráter nacional e democrático que nos aproximarão do último limite da revolução burguesa, assim também no curso da segunda etapa poderá haver fases táticas diversas e sucessivas nas modificações diversas na composição do governo, à medida que fosse crescendo o peso específico dos operários e seus aliados naturais e particularmente no seio das forças anti-imperialistas e antifeudais" (idem). Mesmo quando o autor se refere simultaneamente ao tempo real e aos fins últimos tal sentido aparece: "As modificações na composição dos governos da primeira etapa por aproximação da passagem para a etapa seguinte e as modificações na composição dos governos da segunda etapa nos conduzirão ao nosso ulterior objetivo histórico - a vitória do socialismo" (idem).

Usando a caracterização da posse do poder, Alberto Passos Guimarães demarcava o campo da política para o agir no tempo presente e próximo. No contexto de 1960, a dois anos da Declaração de Março, o autor se empenha em desconstruir a tese de alguns publicistas do V Congresso que diziam que a burguesia já estaria participando do Estado como um todo, ou como classe, dito assim com a intenção conceitual da época. Quer dizer, que tal hipótese levava - equivocadamente, anota Passos Guimarães, retomando ponto anterior - a se pensar que aqui "não há mais nenhuma revolução nacional a realizar", pois já se concluíra o período das transformações anti-imperialistas e antifeudais e se passava ao tempo novo de uma revolução fundamentalmente antiburguesa e anticapitalista. Ao contrário, prossegue o autor, dizer que "A aspiração da burguesia brasileira é, por isso, a de criar um Estado nacional independente em que ela seja a força dominante", como estava nas Teses, propiciava aos atores não só a denúncia do governo da época como também a pressionar para convertê-lo "em governo de coligação nacionalista e democrático" (Passos Guimarães, 1960b). Mudar o governo então existente por outro de caráter nacionalista e democrática não era pouca coisa para o ator que se postasse na política corrente. Requeria descortinar um horizonte que supunha organizar-se à luz do dia, estender-se pelo país, buscar entendimentos que lhe agregassem influência; preparar tarefas eleitorais e assim por diante.

Perseguir mudanças de classes no poder - digamos com linguagem daquele tempo -, visando deslocar classes e grupos mais atrasados e toda a burguesia ligada ao imperialismo significava empenhar-se na formação de sucessivos governos de caráter burguês ("nos quadros do regime vigente", cite-se novamente as Teses), ou seja, ter vida bem ativa na conjuntura daquela época.

Nesse ponto, Alberto Passos Guimarães se diz distante das Teses. Enquanto elas viam tais deslocamentos nos governos como mudanças graduais, "como fases de uma mesma etapa", ele as entendia como alterações na "composição do Estado", vale dizer, como "mudanças radicais", qualitativas "e portanto constantes (grifo do autor do presente texto) de duas etapas em vez de uma" (Passos Guimarães, 1960b). Segundo o publicista, faltara às Teses maior congruência entre o "sentido geral" da sua análise justa da situação concreta brasileira" e o "conteúdo revolucionário" da "nova política" (idem). Citemo-lo numa passagem desse segundo texto ("Uma falsificação e vários erros crassos na questão das etapas"), na qual aparece de modo claro o ponto do agir do protagonista na circunstância e mais precisamente na conjuntura. O decisivo para Passos Guimarães consistia em "distinguir e ordenar, desembaraçar e definir objetivos e tarefas que têm que ser realizadas na ordem cronológicas ou 
histórica, isto é, que terão de ser realizadas proximamente. Só assim se terá clareza sobre as linhas divisórias, os 'instantes estratégicos' em que se modificará a composição do poder e sobre que classes deverão ser desalojadas do poder e que classes entrarão no poder" (idem) ${ }^{47} \mathrm{Em}$ suma, para ele, tratava-se de pensar um processo revolucionário "planejado" como tudo naqueles tempos de inteligentsias leninistas e mannheimianas cujos "passos intermediários" em qualquer desses dois registros comunista ou nacional-desenvolvimentista - eram concretizáveis e cumulativos, em direção aos quais se caminharia no tempo real ali disposto e não por gestos à espera de uma revolução futura.

\section{O papel dos sindicatos no "movimento camponês"}

O tema das etapas não constitui toda a contribuição do autor de Quatro séculos de latifúndio ao pecebismo contemporâneo. Há nos seus textos congressuais um equacionamento antinaturalista da questão agrária que merece exame. Nosso interesse agora é chamar a atenção para sua visão alternativa ao protagonismo camponês diruptivo dos modelos das revoluções burguesas europeias de 1848 e russa de 1905. O modo como o publicista põe o problema da interpelação do nosso campesinato débil aponta para uma ideia de revolução agrária que termina sendo vista como uma revolução concretizável mediante procedimentos democráticos. Com todas suas ambiguidades, o autor realiza, no tema agrário, um exercício formulativo que também podemos habilitar como argumento relevante a favor daquele pecebismo gradualista e de frentismo democrático.

Vejamos o lastro que Alberto Passos Guimarães propicia ao agrarismo que o V Congresso de 1960 oficializa. Como foi observado, o autor influíra na Declaração de Março, nela sendo visíveis suas ideias agrárias. No entanto, será nos artigos dirigidos ao V Congresso já citados ("A questão das etapas da revolução brasileira", "Uma falsificação e vários erros crassos na questão das etapas") e em "Três Frentes da luta de classes no campo brasileiro", nos quais o publicista busca substantivar a nova orientação agrária. Como no tema das etapas, Alberto Passos Guimarães

\footnotetext{
${ }^{47}$ Essa referência a "instantes estratégicos" também lembra a ressalva que fazia Engels ao se referir no seu testamento político à quebra da legalidade pelas forças reacionárias "para deter o avanço socialdemocrata ao socialismo por meio do método eleitoral no regime democrático-constitucional do seu país (Engels, 1895; 1977).
}

sustenta sua argumentação no método leniniano da luta de classes que, segundo ele, rompia com a "sociologia vulgar" incapaz de penetrar no "âmago" do problema agrário, "dele tendo-se apenas uma visão estática, um quadro fenomenológico” (Passos Guimarães, 1960c).

Passemos às proposições do autor, particularmente a que se refere a uma variante de revolução agrária diferenciada tanto da fórmula nacionallibertadora (III IC) quanto da própria teoria leninista da revolução democrático-burguesa de novo tipo. O publicista radica seu ponto de partida na fragilidade dos nossos camponeses, aludindo a uma passagem de Lênin em que o teórico russo imaginava a eventualidade de um segundo (segundo em relação ao próprio modelo leniniano no qual o campesinato constitui força primordial) tipo de revolução diverso da matriz originária de Marx e Engels. ${ }^{48}$ Antes, porém, fixemos dois pontos: a) que, como temática, há em Caio Prado Jr. uma clara ideia de revolução não camponesa, conceito este, já veremos, posto em circulação por Lênin em um dos seus textos sobre a revolução russa de 1905; e b) como noção da cena do V Congresso de 1960, aquele conceito leniniano aparece justamente com um dos artigos de Alberto Passos Guimarães.

Para diferenciar o sentido da revolução agrária não camponesa em Passos Guimarães, façamos uma breve referência a Caio Prado. Escrevendo na Tribuna de debates da primeira convocatória do IV Congresso (1947), já tendo publicado Formação do Brasil contemporâneo (1942) e História econômica do Brasil (1945), dizia Caio Prado que - "na forma em que se coloca em geral entre nós a questão da revolução democrático-burguesa" aqui não ocorreria nenhuma revolução como trânsito do feudalismo para a ordem burguesa. A circunstância brasileira consistia em uma economia que desde sua gênese se organizara como economia colonial (Prado Jr., 1947). ${ }^{49}$

\footnotetext{
${ }^{48}$ Considera-se aqui como emblema da matriz dos clássicos o modelo que Engels desenha no seu texto "O Problema camponês na Franca e na Alemanha" (Engels, 1894; 1981).

${ }^{49}$ Vale a pena ver um trecho do artigo "Os fundamentos econômicos da revolução brasileira" (1947): "Não é assim uma economia feudal nem 'relações feudais de produção' que representam a primeira etapa da evolução histórica brasileira. É uma organização econômica que poderíamos designar por 'colonial', caracterizada pela produção de gêneros alimentares e matérias-primas ao comércio internacional e fundada (em seu setor agrícola que é o principal) no sistema de plantação, isto é, num tipo de exploração em larga escala que emprega o trabalho escravo. A substituição posterior do trabalho escravo pelo trabalho emprega o trabalho escravo. A substituição posterior do trabalho escravo pelo trabaho
juridicamente livre (mas submetido de fato a um sem número de restrições) introduziu naquele sistema um poderoso fator de desagregação que o comprometerá definitivamente.
} 
Recordemos que o autor já cogitava que aqui teríamos uma revolução sem classe econômica forte e protagonista e que também já tinha em mente que o processo brasileiro tampouco contaria com um campesinato revolucionário. Estaríamos diante de um capitalismo socialmente excludente e sem condições para reestruturar-se caso não adviesse grande intervenção do poder público. Vale dizer, estávamos ante uma modernização cuja revitalidade residia no renovamento do mundo agrário que, no entanto, não seria liderado por um campesinato ativo.

Em Caio Prado, a "revolução nacional" dependia menos de um antiimperialismo unificador do espírito nacional e sobredeterminante das demais contradições e conflitos, como nos exemplos sempre citados das resistências anticolonialistas. Entre nós, a questão nacional consistia no grande esforço para tornar o capitalismo existente mais produtivo e incorporador. Ao contrário da fórmula antifeudal e anti-imperialista, Caio Prado Jr. radicava a revolução numa "contradição fundamental" (noção da época) de outro tipo: a incapacidade de um capitalismo de tornar produtivos vastos contingentes sociais, sobremaneira os desvalidos do mundo rural. Daí a fórmula caiopradiana da revolução agrária e nacional sugerir uma reestruturação ao modo americano no sentido de um Oeste-mercado interno (mundo rural) que complementasse um Leste-industrial. "Oeste" pensado como uma revolução não camponesa conquanto seria uma grande mobilização assentada na proteção de direitos dos grupos mais expressivos da força de trabalho empregada nos grandes setores da agropecuária. Esse "movimento social reivindicativo" (sic) viria universalizar processos sociopolíticos sob a liderança de sindicatos espalhados pelos municípios brasileiros à frente de reivindicações por salário e ocupação sobretudo daquele núcleo estratégico dotado de melhores condições para difundir impulsos renovadores na economia agrária de modo sustentável.

Mas não modificou fundamentalmente, desde logo, os quadros essenciais da estrutura agrária vigente. E é precisamente aquela contradição introduzida no funcionamento primitivo do sistema agrário pela libertação do trabalho que constituirá o fator máximo de transformação econômica e social ora em curso e que devemos revolucionariamente levar a seu termo".

\section{Lênin e a revolução agrária não camponesa}

Vejamos agora como a ideia de revolução agrária não camponesa circula no V Congresso com Alberto Passos Guimarães. Leitor dos textos leninianos sobre a revolução burguesa na periferia capitalista, o publicista figura entre os primeiros a se referir às formas farmer e prussiana de evolução do atraso rural para o moderno, descritas pelo marxista russo em O programa agrário da social-democracia russa (1907). Em Passos Guimarães tanto há menções a traços prussianos em processos de nossa modernização rural, como mencionaremos mais adiante, quanto o uso do conceito de revolução agrária não camponesa. Em "Três frentes da luta de classes no campo brasileiro", o autor retoma o tema da revolução agrária a partir do cenário de um mundo colonial diverso do modelo da III IC, levantando a hipótese de podermos conhecer aqui uma revolução democrático-burguesa com um campesinato bem pouco "desenvolvido". Com essa tematização, Alberto Passos Guimarães diferencia o "problema camponês" tanto da vulgata marxista-leninista (não o subsumindo à noção de aliança operário-camponesa) que marcava áreas importantes do partido comunista quanto em relação à ideia caiopradiana de revolução não camponesa protagonizada do "começo ao fim" do processo revolucionário por grupos "não camponeses".

Em "Uma falsificação e vários erros crassos na questão das etapas", o autor recorre a passagens do opúsculo leniniano de 1907 quase desconhecidas na cena pecebista, delas extraindo justamente o conceito de revolução agrária não camponesa. ${ }^{50}$ Passos Guimarães traz o conceito para registrar ser possível aqui um processo de transformação agrária conforme a hipótese de Lênin: com lógica e forma diversas da revolução camponesa antifeudal. Anote-se que, no autor russo, trata-se de uma modalidade que ocorreria nos países dotados de agricultura totalmente capitalista ou naqueles outros casos em que o seu "regime agrário" já se achava tão "amalgamado" com a "economia capitalista em geral" que "seria impossível destruir este regime sem destruir o capitalismo" (cf. Passos Guimarães, 1960b). Esse tipo de revolução poderia ser liderado por outras classes (no exemplo do próprio Lênin, burguesia industrial e proletariado) e

${ }^{50}$ Há um ensaísta bem posterior que faz referência à hipótese leniniana acima aludida em um registro sobre a relação entre o encaminhamento do tema agrário e o formato do político (Vianna, 1976). 
teria por objetivo abrir caminho para o capitalismo agrário. Alberto Passos Guimarães retinha a problematização leniniana para repensar o problema camponês brasileiro, citando do opúsculo de 1907 esta passagem: "Em outras palavras, é possível um país burguês sem camponeses. É possível uma revolução burguesa em um país de considerável população camponesa e que, não obstante, essa revolução não seja camponesa, isto é, seja tal que não revolucione as relações agrárias que afetam em especial os camponeses e não destaque estes entre as forças sociais, sequer ativas, executoras da revolução" (idem). Sublinhe-se o final dessa citação conquanto será ela elemento distintivo na apropriação que Alberto Passos Guimarães faz do leninismo em relação aos temas agrário e da mediação camponesa.

Diferentemente de Caio Prado Jr., nosso ensaísta não leva às últimas consequências a ideia de revolução agrária não camponesa. Ele traz o conceito leniniano para um ponto sobre o qual atribuía importância decisiva: o fato de o Brasil ser "um país de campesinato recente, de movimento camponês atrasado", tudo ainda por se desenvolver por meio da luta de classes. Também aqui poderia ter andamento uma revolução (uma "reforma agrária", como chamava ao tom daqueles tempos) que viria dizia o autor bem próximo das palavras do marxista russo - " "revolucionar' várias relações agrárias que afetam os camponeses mas não os afetam em especial, tais como a destruição de muitos vestígios medievais, feudais, escravistas" (idem). Por esta proposição, Alberto Passos Guimarães diz que a brasileira seria uma revolução rural que começaria a partir de uma base de apoio criada pela luta de classes, isto é, por meio de um "movimento" não camponês. Ela poderia iniciar-se a partir de uma mobilização de assalariados e semiassalariados agrícolas (ou, repetindo os termos das Teses: ter suas "bases iniciais" nos sindicatos que o PCB organizava com vistas a alcançar o campesinato). Reafirmando a Declaração de Março e o caminho andado até a organização da Ultab, em 1954, assim as próprias Teses definiam o novo caminho: "A fim de impulsionar a organização das massas do campo, é necessário atribuir uma atenção primordial aos assalariados e semiassalariados agrícolas. Em virtude da sua condição social de proletários ou semiproletários, como também do seu grau de concentração, os assalariados rurais são mais suscetíveis de organizarem-se em sindicatos que podem constituir as bases iniciais para a mobilização das massas camponesas. Essa mobilização exige, igualmente, que se parta das condições atuais do movimento camponês e se tomem por base as reivindicações mais imediatas e viáveis como a baixa das taxas de arrendamento, a prorrogação dos contratos, a garantia contra despejos, o pagamento do salário mínimo, a legitimação das posses etc., não devendo ser propostas, no trabalho prático, palavras de ordem que ainda não encontram condições maduras para a sua realização. Também no campo, a prática demonstra que a atuação através das formas legais de luta e de organização é aquela que permite às massas alcançar êxitos, devendo ser estudadas e adaptadas às condições de cada região as experiências das ligas camponesas, associações rurais e cooperativas, bem como impulsionada a organização dos assalariados e semiassalariados agrícolas em sindicatos. No processo de associação dos assalariados e dos camponeses é de grande importância a defesa jurídica dos direitos que lhe são assegurados. A ação das massas camponesas é indispensável para vencer a resistência dos latifundiários no Parlamento e conquistar a aprovação de leis que atendam aos seus interesses, inclusive a elaboração de uma legislação trabalhista adequada ao campo. Em torno da reforma agrária, necessidade hoje nacionalmente reconhecida pelas forças do mais variado caráter, cumpre aos comunistas elevar suas atividades entre as massas. A reforma agrária deve tornar-se bandeira dos próprios camponeses, o que coloca em primeiro plano a questão das formas de sua mobilização e organização, a fim de que avancem por sua própria experiência política" (PCB, 1960; 1982: 72-73).

O eixo desse agrarismo consistia, assim, em uma mediação organizacional habilitada a operar uma mobilização de porte visando envolver a grande massa dos camponeses. Em termos a que muito se parecem as palavras das Teses, diz Passos Guimarães: "E, à medida que os camponeses forem levados a participar do movimento agrário, conduzido pelo proletariado em aliança com este, a reforma agrária ainda não camponesa se transformará numa reforma agrária camponesa, o que acontecerá na segunda etapa da revolução anti-imperialista e antifeudal" (Passos Guimarães, 1960b). Essa grande movimentação social - o "movimento camponês" - era concebido como uma articulação entre aqueles dois contingentes, coligados, desde logo, com os operários urbanos, a classe revolucionária que haveria de levá-los, sob sua direção - reitera o autor (no sentido da tese da aliança operário-camponesa) - a participar da frente única "nacional" e "democrática", a composição política que daria vida ao processo revolucionário no Brasil nos seus primeiros tempos (idem). 
Entretanto não se pode minimizar o fato de que a "nova compreensão" de 1958 entendia o problema agrário não como questão nacional, mas como uma segunda "contradição fundamental" determinada pela dependência. À lógica desta última circunstância se subsumiriam os demais tensões da formação social; o anti-imperialismo se constituindo em contradição sobredeterminante. Além de expressar aquela época desenvolvimentista, a principalidade que se sublinhava naquele postulado ainda recebia certa influência conceitual da Revolução Chinesa na qual a luta nacional contra o invasor estrangeiro fora vitoriosa (categorias como: "contradições", "contradição principal", etc.). Assim, o ponto forte do ensaísta se ofusca à hora que o autor ajusta a fórmula leniniana à questão da dependência na periferia capitalista. Como que se dilui a densidade das citações do clássico a que recorre o comunista brasileiro ao equacionar a "revolução nacional" na encruzilhada dos caminhos prussiano ou revolucionário; vigor este que Alberto Passos Guimarães também exibe quando se volta para o tema da debilidade do nosso campesinato no registro dos "restos feudais", todavia parecendo ter em mente os textos leninianos citados.

De qualquer modo, o autor constrói argumentação em suporte à "nova política" com base em um cânone ao mesmo tempo de interpretação e programático. Trata-se da luta de classes, o "elemento dinâmico", como a chama, movido contra o "naturalismo histórico", viés que, segundo ele, leva à proposição de que o avanço do desenvolvimento capitalista torna desnecessária a reforma agrária (Passos Guimarães, 1963). O ponto específico do qual parte nosso ensaísta leninista - também autor nacional-desenvolvimentista ao falar a outra linguagem daquele tempo - consiste na "luta das classes em ascensão" (grifos do autor destas notas). Ou seja, esse fio condutor "que nos levará a descobrir as leis gerais e particulares do desenvolvimento social" (Passos Guimarães, 1960c). Passos Guimarães concentra seu olhar naquele bem preciso "elemento dinâmico que aciona o progresso social" (sic), nas novas classes: o proletariado, os camponeses e a intelectualidade.

$\mathrm{O}$ autor considera o campesinato como um grupo emergente (idem) dentre as classes convocadas a abrir caminho progressista ao desenvolvimento capitalista. Acrescente-se a seguinte observação com que Passos Guimarães qualifica o "ponto de vista do proletariado" a que serve sua publicística: ${ }^{51}$ o proletariado se distinguia das classes oprimidas pela burguesia - diz ele citando a Lênin - como aquela classe que não cifrava suas esperanças "sobre uma interrupção do desenvolvimento burguês; não sobre o enfraquecimento ou atenuação da luta de classes, mas ao contrário sobre seu desenvolvimento mais completo e mais livre", cf. idem). Aliás, esse era um tipo de tematização que aproximava o pensamento comunista "péssimo" na teoria e lúcido e responsável quando referido à prática (Jaguaribe, 1977, apud Marçal Brandão, 1992) - da cena intelectual-política que os autores isebianos e cepalinos construíam com muita competência.

Como vimos no tópico anterior, Alberto Passos Guimarães olhava os anos desenvolvimentistas ancorado nas teses leninistas sobre a revolução na periferia capitalista. Reconhecer como inevitável a modernização (de conteúdo econômico e social burguês, este o aspecto "objetivo" do problema) importava atentar para a encruzilhada que estava posta ao país: as rotas conservadora e progressista. A circunstância de um industrialismo retardatário numa periferia capitalista realçava como tema crucial da revolução brasileira a questão das coligações que disputavam a hegemonia do nosso curso modernizador.

É nesse quadro conceitual que o autor põe o tema agrário na revolução. Segundo ele, aqui também não se avançara: a raiz da "compreensão nova" não aparecera de forma clara na Declaração de Março e ainda não estava posta nas Teses do V Congresso. Alberto Passos Guimarães ia diretamente a $O$ programa agrário da social-democracia russa: "Dois são os caminhos possíveis do desenvolvimento capitalista no campo brasileiro: um, revolucionário, outro, reformista" (Passos Guimarães, 1960c). A ser apoiado pelo proletariado - retoma o leninismo o primeiro deles consistiria em transformações burguesas "que resultem na destruição dos laços com o feudalismo, que resultem na destruição das formas pré-capitalistas, e expressem um desenvolvimento democrático apoiado no capitalismo de Estado e na propriedade camponesa" (idem). Já o caminho "reformista" (aqui as aspas devido ao uso do termo para referir-se à via junker) também imporia ao mundo rural mudanças burguesas, mas

${ }^{51}$ A noção "ponto de vista do proletariado" é tomada de Adolfo Sánchez Vásquez em sua crítica ao teoricismo da obra de Althusser (Vásquez, 1978). 
sem alterar as bases do ancien régime. ${ }^{52}$ Ainda nessas passagens sobre aquelas duas vias, Passos Guimarães adicionava uma segunda qualificação que extraía da circunstância nacional, a saber: as transformações burguesas poderiam realizar-se sob formas diversas "e o tem sido no Brasil quer de forma violenta, quer de forma pacífica, sem ou quase sem violência" (idem). Esse tema se faz presente em Quatro séculos de latifúndio, e acompanha passagens dos textos congressuais, particularmente do artigo ora em exame.

Esse ponto da "forma de luta" (linguagem da época) não reflete apenas interesse historiográfico e voluntarismo do nosso autor. Constitui um elemento condicionante das possibilidades do novo agrarismo. Os capítulos de Quatro séculos de latifúndio dedicados aos três primeiros séculos da Colônia realçam a forte presença da violência no mundo rural. Desde o uso direto na época da constituição da grande propriedade estamental, passando pela estratificação no sistema rígido da casa-grande até os choques com os "intrusos" e "posseiros" que espreitavam os grandes domínios (Passos Guimarães, 1963). No terceiro texto congressual, o autor registra que, após todo um tempo penoso de conflitos e levantes de escravos, o movimento abolicionista concluíra-se como uma vitória pacifica. A Abolição constitui o primeiro emblema de uma via que abre caminho para novas relações econômicas e sociais e adquirira "importância revolucionária", mesmo tendo se conservado o monopólio da terra (Passos Guimarães, 1960c). Sublinhava que 1888 trouxera um tempo de "transformações burguesas de conteúdo revolucionário", antecedendo a outras mudanças que seriam também obtidas por meios pacíficos mediante "reformas" (as aspas devido à conotação

${ }^{52}$ Merece um excurso a leitura conjunta de Duas da social-democracia russa e de $O$ programa agrário da social-democracia russa como textos nos quais Lênin expõe sua teoria da revolução burguesa de novo tipo. No primeiro deles, Lênin esclarece as vantagens do caminho capitalista revolucionário: "Em países como a Rússia, a classe operária sofre não tanto do capitalismo como da insuficiência do desenvolvimento do capitalismo. Por isso a classe operária está absolutamente interessada no mais amplo, mais livre e mais rápido desenvolvimento do capitalismo. É absolutamente vantajosa para a classe operária a eliminação de todas as reminiscências do passado que entorpecem o desenvolvimento amplo, livre e rápido do capitalismo" (Lênin, 1905; 1975). Observe-se que a Declaração de Março considera o desenvolvimento capitalista como o "elemento progressista por excelência" da economia brasileira do tempo contemporâneo. Repetido nas Teses do V Congresso, esse desenvolvimentismo provocou uma reação ortodoxa ao que então se chamou de "objetivismo" burguês prussiana acima referida). Alberto Passos Guimarães alude às ações mais contemporâneas de posseiros pela validação dos títulos de suas propriedades. $\mathrm{O}$ ponto alto desses conflitos tensos, porém bem-sucedidos, será a expropriação do Engenho da Galileia. Sob o curso "normal" dos acontecimentos, o conflito foi igualmente exitoso ("Apesar de concretizada mediante uma 'reforma' concedida pelo governo, a expropriação não teve conteúdo reformista, não se fez para conservar as velhas relações de produção existentes", cf. idem). Ante um novo emblema, o autor diz que eventos como aqueles se repetiriam "em elevada escala" à medida que a luta de classes tivesse curso livre e o movimento camponês se fortalecesse. ${ }^{53}$

Realcemos que Alberto Passos Guimarães retém daquelas referências tema essencial: a "forma pacífica é mais vantajosa e mais eficaz do ponto de vista da prática revolucionária, que a forma violenta." Ele anota que o recurso à violência verifica-se com mais frequência em processos "prussianos" (de cunho "reformista" por representar "uma conciliação com as formas de dominação correspondentes a regimes historicamente superados", cf. idem). Nessa passagem, o autor põe como exemplo o caso da evolução do "latifundismo feudal para o latifundismo burguês, principalmente na agricultura cafeeira", onde, registra ainda, em muitos casos, a classe opressora tomara a iniciativa de recorrer a meios violentos (idem).

Atualizada pelo conflito da Galileia, a questão do curso "normal" dos acontecimentos em sistema político aberto será visto como terreno propício ao alargamento organizacional e à concretização das mudanças agrárias. $\mathrm{O}$ autor sugeria que, dinamizada, a frente única "nacional e democrática" criava oportunidades políticas a que os protagonistas podiam recorrer para levar os conflitos a "desfecho pacífico". Essa era uma vantagem construída no contexto de uma coligação entre vertentes reformadoras, no seio das quais havia lugar para o grupo social da Galileia. Residia no ambiente políticodemocrático e nessas interconexões a possibilidade de se "transformar os exemplos isolados de nossa história em regra de conduta da luta de classes no campo, isto é, se conseguirem (as forças reformistas) multiplicar por toda parte as reformas (pacíficas) de conteúdo revolucionário" (idem). Os obstáculos a tal caminho dependeriam da reação conservadora e da

53 Chama a atenção o fato de Pernambuco ser emblemático tanto para Alberto Passos Guimarães (o Engenho da Galileia) como para Caio Prado que às vésperas de 1964 tomava como modelo do seu agrarismo as greves ocorridas em 1963 na zona da Mata daquele Estado. 
resistência que lhe interpusesse o movimento democrático, termo com que o autor aludia ao conjunto dos grupos coligados na frente única da época. Inclusive, nessa correlação de forças, o fato de o próprio uso da violência "passar às mãos dos inimigos do povo" assumia "transcendental importância como fator político favorável à mobilização das massas populares e ao desenvolvimento da revolução" (idem), diz Alberto Passos Guimarães sugerindo que, sob o regime democrático, é por demais valioso ao protagonista ter iniciativa no campo da política.

\section{Os fundamentos práticos da mediação política}

Após apresentar esses traços do "movimento camponês", o autor retoma o cânone da luta de classes "sob um outro aspecto". Relembremos que para ele a luta de classes não só constitui método adequado aos estudos de história agrária como também assinala o "caminho brasileiro" da revolução "antifeudal". O texto "Três frentes da luta de classes no campo brasileiro" traz uma pequena narrativa sobre o atraso do campesinato que suscita no autor uma estratégia para estimular o livre desenvolvimento da luta de classe no mundo rural. Nesse texto, Alberto Passos Guimarães passa do registro da debilidade camponesa à outra linha argumentativa, de sentido "mais prático": ao tema da mediação requerida para a ativação da luta de classes dos grupos agrários (ainda sem "caráter aberto e consciente", cf. Lênin).

Referindo-se ao campesinismo ("exagerado") dos anos da Guerra Fria, Alberto Passos Guimarães faz esta observação aparentemente trivial: "Partindo de premissas certas de que havia forte semelhança entre a situação de miséria e opressão feudal em nosso país e a de vários países asiáticos e do leste europeu, os comunistas tiravam conclusões erradas sobre uma inexistente analogia entre o grau de maturidade do movimento camponês brasileiro e o de outras partes do mundo" (idem). À circunstância de termos aqui um campesinato "muito recente" somava-se o fato de que, diversamente da experiência de outros países, nossa história conhecera "um número de levantes camponeses que se contam nos dedos". Na Rússia, até 1905, haviam ocorrido mais de 2000 levantes de importância. No Ocidente da Europa havia casos de guerras camponesas que perduram por séculos, para não falar da China, continua o autor, de tradição mais milenar ainda, onde tiveram curso as revoluções de 1928-37 e de 1949. Enquanto entre nós, as transformações do mundo rural foram de outro tipo, inclusive a
Abolição, a mais radical delas - emblema dos clássicos - resultara inclusive de um movimento "impulsionado e dirigido pela pequena burguesia urbana" (idem), o qual, como já mencionado, tivera desenlace no contexto de um curso "normal" dos acontecimentos, no ocaso do Império e do seu sistema político elitista.

Ainda segundo o autor, o atraso do "movimento camponês" não era só em relação às ações e levantes rurais daqueles países mas também se mantinha descompassado com respeito ao próprio "movimento democrático em geral" que, nos anos posteriores ao 24 de agosto de 1954, rapidamente se expandira adquirindo ampla composição. O protagonista revolucionário necessitava entender essa especificidade e já não mais recorrer a "meios artificiais" para alcançar o campesinato. Meios que só levavam os protagonistas a militar em uma "imaginária" revolução rural "com a imposição de práticas aventureiras e desesperadas, completamente desligadas da realidade" (idem). Seria esse o caso de se cogitar em mover quatro ou cinco dezenas de quadros para "levantar os camponeses" "distribuídos por dois milhões de estabelecimentos agrícolas ao largo do país." Diferente disso, a "nova tática de mobilização de massas no campo" (sic) consistia numa mediação política referida a uma dinâmica social assentada em relações entre classes e interesses, em contexto organizacional de tipo permanente (os sindicatos).

Pela linguagem com que valoriza o papel dos sindicatos, à primeira vista parece que Alberto Passos Guimarães apenas reflete o obreirismo dos PCs, seguindo a fórmula leninista-staliniana da aliança operário-camponesa e seu pressuposto de "classe universal" urbana. No entanto, observe-se que o autor não perde de vista as singularidades anteriormente referidas - a "contemporaneidade" do campesinato brasileiro, sua pequena tradição de conflitos e debilidade organizativa. Inclusive a periodização (desde a gênese) utilizada pelo autor para reconstituir o "desenvolvimento da luta de classes no campo" tem um sentido valorativo do protagonismo camponês. Este ponto historiográfico marca Quatro séculos de latifúndio. Os capítulos dedicados aos primeiros tempos dos "senhorios" e dos "intrusos" e "posseiros" compõem a circunstância de enorme dependência sob a qual emergem os desvalidos rurais; tema ao qual retornaremos ao final destas notas. Por ora, realcemos, em "Três frentes da luta de classes no campo brasileiro", a referência ao fato de a "luta de classes no campo" em seu curso contemporâneo e mais recente ter se desenvolvido cada vez mais 
(naquele tempo) por "via pacífica e concessões de governo" (Passos Guimarães, 1960c).

Nessa passagem desse texto, o autor volta a se referir ao campesinismo pecebista ("foquista" e de "zonas liberadas", de inspiração maoísta) dos anos da Guerra Fria. É sob esse prisma autocrítico que dedica um tópico à ênfase na mobilização dos "empregados agrícolas", grupo no qual, recorde-se, Caio Prado assentava o "movimento social” não camponês do "começo ao fim" da revolução agrária. Citemos Alberto Passos Guimarães: "Afastando-se dessas delirantes fantasias (enviar "missionários" a dois milhões de estabelecimentos rurais para ativar os camponeses, RS), as 'Teses' apontam a maneira certa de atingir em larga escala as massas do campo através dos assalariados e semiassalariados agrícolas, organizando-os por meios legais em suas associações de classes, despertando-os para a luta por seus direitos e reivindicações, elevando o grau de consciência da sua luta de classe" (idem). ${ }^{54}$

Pensamento novo em mentalidade ortodoxa carrega não poucas ambiguidades. Em sua referência à ação de porte entre "empregados agrícolas", Passos Guimarães traz à forma sindical a partir da qual começa essa "mobilização das massas do campo" alusões intercambiáveis com a ideia da superioridade proletária oriunda da noção de aliança operáriocamponesa. Uma delas aparece quando o autor diz em linguagem bem antiga que será por meio desse tipo de mediação que se montará as "correias de transmissão" que "irão ligar o proletariado e o movimento democrático das cidades aos camponeses e ao movimento democrático do campo" (idem); "correias de transmissão", como se sabe, a expressão consagrada por Stálin, referindo-se ao mundo revolucionário do seu tempo (Stálin, 1949).

Ainda nesse tópico dedicado à mediação social, o autor traz a controvérsia sobre o capitalismo agrário em desacordo com Caio Prado. Suas advertências estão dirigidas aos exageros "quer a respeito do predomínio das formas capitalistas de trabalho, quer a respeito do papel ainda absoluto das formas pré-capitalistas de trabalho". A primeira restrição

\footnotetext{
${ }^{54}$ Vale a pena aludir à rota que o PCB segue na sua evolução rumo ao sindicalismo na passagem do pior tempo da Guerra Fria aos anos 1950, deslocando-se de um ponto ao Norte para São Paulo. O MST faria depois caminho similar, vindo de um outro ponto, ao Sul, em busca daquele mesmo "coração político" de onde se expandiria pelo país.
}

se expressava no desenvolvimento dos sindicatos ainda não "muito grande", tornando-o "tarefa difícil" que não dependia "apenas da dedicação e do valor pessoal dos quadros comunistas, mas principalmente do apoio do movimento democrático, da cidade e do campo, em favor da extensão, ao meio rural, dos direitos consagrados na legislação trabalhista" (Passos Guimarães, 1960c). Com estes grifos sugerimos que ali Passos Guimarães faz referência tanto à política como dimensão da generalidade de que fala Lênin em Que fazer $?^{55}$ quanto ao caráter expansivo do sindicalismo, neste ponto concordando (parcialmente) com Caio Prado. Era difícil ignorar na discussão congressual de 1960 o tipo de associativismo no qual o historiador vinha insistindo há muitos anos.

Nessa mesma passagem de "Três frentes da luta de classes no campo Brasileiro", Alberto Passos Guimarães também apresenta o problema camponês comparando, com dados do Censo de 1950, a dimensão numérica - bem maior - da pequena agricultura em relação ao avanço das formas capitalistas de emprego. Mesmo aí o autor volta ao sentido político da mediação fazendo o contraste entre interpelação social versus subjetivismo e novamente chama a atenção para o sindicalismo que, em todo caso, então recebia estímulo do desenvolvimento (ainda lento) do capitalismo rural repete o ponto -, o avanço dos sindicatos dependendo principalmente do movimento democrático das cidades e do mundo rural (idem).

Ainda no texto ora comentado, o autor traz à "nova compreensão do problema agrário" o tema da diferenciação social. No tópico "A frente contra o latifúndio", Alberto Passos Guimarães recorre a categorias econômicas mostrando a composição segmentada da classe do "passado contemporâneo": a) aqui tínhamos um campesinato composto por extratos conforme o tipo de renda que assegurava sua dependência ao monopólio da terra; a renda-trabalho trazia o primeiro tipo de camponeses pré-capitalistas (moradores, agregados e todos os que realizavam prestação de serviço gratuito ou semigratuito); por meio da renda-produto, meeiros e parceiros; no caso dos trabalhadores sujeitos à renda-dinheiro: rendeiros, foreiros e arrendatários não autônomos ou semiautônomos; e b) por outro lado, havia

\footnotetext{
55 Como se sabe, uma das acepções de política exposta em Que fazer? diz respeito à consciência que os grupos subalternos podem adquirir em suas próprias relações com as demais classes da formação social, particularmente em suas experiências ao se relacionarem
} com a dimensão da generalidade representada no Estado. (Lênin, 1902; 1975). 
um campesinato de formação burguesa: os que possuíam domínio ou posse da terra (proprietários, arrendatários capitalistas, ocupantes e posseiros) (idem). Os protagonistas dessa frente contra o monopólio da terra seriam grupos diversos que, em comum, almejavam o desenvolvimento de relações capitalistas ("que importam em melhorar suas condições de vida"); uma massa heterogênea, em palavras do próprio Passos Guimarães, de camponeses semifeudais, camponeses pequeno-burgueses e camponeses burgueses (idem). Classe "muito recente" do "passado contemporâneo" que viria compor as reivindicações do "movimento camponês" sem que seus animadores consultassem a hierarquia que, segundo eles próprios, estruturava o processo de ativação social, vale dizer, a predominância de um grupo mais coeso e organizável viabilizando a interpelação do elemento diversificado "camponês".

Vejamos agora o sentido que predomina em "Três frentes da luta de classes no campo brasileiro", começando pelo seu ponto principal: não teríamos aqui apenas duas áreas de conflito agrário - as frentes dos camponeses contra os restos feudais e dos assalariados ou operários agrícolas contra o patronato rural, como sugeriam citações leninianas correntes no PCB. Em razão de termos uma agricultura semifeudal em periferia dependente, Alberto Passos Guimarães reivindica que também se reconhecesse ao anti-imperialismo função sobredeterminante no mundo rural. Ao terminar esse artigo com o visor da "contradição principal" (a espoliação das empresas estrangeiras no mundo produtivo agrário), o autor enfraquece a argumentação inspirada em Lênin desenvolvida em outras passagens do texto ora comentado e especialmente em "Uma falsificação e vários erros crassos na questão das etapas".

$\mathrm{O}$ encontro do tema da dependência com a abordagem atenta à particularidade de estarmos na periferia capitalista não mostra as marcas das "sedimentações passivas" que uma interseção como esta deixaria na formação social; exercício que o autor faz em relação à feudalidade, em outras passagens dos textos comentados. Dir-se-ia que há dois movimentos. De um lado, o sentido geral da "revolução nacional" leva Passos Guimarães a associar o mundo rural ao dinamismo do campo democrático; de outro, quando traz o nexo imperialismo-questão agrária não expõe incidência política como a que lhe propicia a conceituação leniniana no tema da revolução agrária "inicialmente não camponesa". Em suma, sente-se falta, no último tópico do artigo ("A frente da luta contra o imperialismo"), de referências à gênese, evolução burguesa e dependência com sentido formulativo, como em Caio Prado, ensaísta que - ao possuir interpretação de Brasil - elabora teoria própria sobre a colônia de produção, tem excursos sobre nosso industrialismo débil e chega, como vimos, a um agrarismo sindical bem preciso, pontos que o acompanha por toda sua publicística.

Embora não chegue a ser uma tematização daquele tipo, a ênfase que Passos Guimarães põe na falta de autonomia dos camponeses adquire realce quando se atenta às linhas gerais com que outros ensaístas descrevem os desvalidos rurais. Mencione-se brevemente que tivéramos aqui uma força de trabalho trazida de fora e subjugada manu militari no grande empreendimento econômico, a qual, depois da Abolição, já livre mas abandonada à própria sorte, como sublinharam Joaquim Nabuco e Gilberto Freyre, terminaria sujeita a novas formas de subordinação. Uma mão de obra mobilizada em proveito da expansão da grande lavoura mesmo tendo sido golpeada pelo fim do trabalho escravo (Alberto Passos Guimarães faz esta anotação em seu livro de 1963). Força de trabalho livre que passaria a viver, como diria Nelson Werneck Sodré, um processo de "regressão feudal", no sentido de constrangimentos recriados (Sodré, 1962). No próprio Quatro séculos de latifúndio, Alberto Passos Guimarães disserta sobre esta circunstância do pós-88. Recorrendo a Marx, especialmente ao capitulo XXV de $O$ Capital, o autor se refere ao nosso "episódio da colonização estrangeira" ao modo da "colonização sistemática" imaginada por Walkefield. ${ }^{56}$ Essa leitura da nova subordinação do trabalho livre tornase mais legível à luz da obra que Barrington Moore nos brinda sobre as vias de acesso mundo moderno, particularmente com sua descrição dos sistemas repressivos de mão de obra agrícola reintroduzidos em tempo contemporâneo, como na Alemanha. Constrangimentos esses que são realçados como ingredientes da modernização conservadora (Moore, 1983).

${ }^{56}$ Citemos a monografia de 1963: “A 'colonização sistemática' fundava-se no princípio de que as terras virgens não deviam ser postas ao alcance das populações pobres por preços baixos, a elas acessíveis, por que se assim acontecesse, os homens e mulheres mais capazes se transformariam em produtores independentes em vez de se engajarem como trabalhadores nas propriedades latifundiárias" (Passos Guimarães, 1963; 1968: 110). Em vez de terra livre ao modo do Homestead Act, aqui se inventara mecanismos que conservavam a força de trabalho sob tutela. Primeiro, a Lei de Terras (1850) se antecipara dificultando o acesso a terra por meio da posse ou da compra a baixo preço; e depois, vieram a "solução astuciosa" (sic) da parceria e as normas disciplinares da "locação de serviços" (idem:135), recriando constrangimentos pretéritos por meio de instituição "moderna". 
No último tópico de "Três frentes da luta de classes no campo brasileiro", Alberto Passos Guimarães subsume a revolução agrária não camponesa ao determinismo anti-imperialista, minimizando as qualificações com as quais lhe dera contornos particulares. Para o autor, de "natureza um tanto diversa" e de maior valor estratégico, a "contradição principal" com o elemento externo gerava uma tensão "ainda mais ampla" que as duas outras "contradições fundamentais", lembrando aqui os documentos comunistas e as Teses do V Congresso, antifeudal e anti-imperialista (PCB, 1960). Em tanto obstáculo ao desenvolvimento nacional, o autor vê na dependência a fonte de uma opressão para as massas rurais "ainda mais dolorosa" do que a opressão feudal (Passos Guimarães, 1960c). Tínhamos aqui uma circunstância distinta do sistema existente na Rússia ou no Japão do começo do século XX: a "feudalidade" brasileira recriava o caráter "dependente e semicolonial" que no século XIX marcara nossa economia agrária, permanecendo ainda muitos desses traços, passada a segunda metade do século XX. Assim se referia Alberto Passos Guimarães a tal hibridação: “... ela é uma agricultura semifeudal de tipo peculiar, baseada na monocultura de exportação, implementada e ainda mantida sob determinadas condições e determinadas limitações impostas segundo os interesses dos grupos econômicos estrangeiros" (idem). Este sistema - assim completa o autor sua referência à circunstância colonial-dependente - não seria uma "abstração" se examinado à luz da categoria econômica "ainda pouco estudada em nosso país": "o sistema do capital comprador" (idem). E dava definição ao conceito: o "conjunto de relações econômicas que atua, quer na produção, quer na distribuição dos produtos destinados ao mercado exterior. Para que as relações econômicas de tal natureza tenham existência material, eles exigem uma rede de empresas e de agentes cuja função, em última análise, é extrair processos extorsivos de coação econômica e extraeconômica, inclusive pelos processos de acumulação primitiva, a maior possível da mais valia dos camponeses trabalhadores" (idem).

Nessa passagem do texto, não advertimos uma interseção do tema do monopólio da terra com uma reorganização da força de trabalho livre que o "capital comprador" - seguindo o ponto do autor - traria a partir da sua presença em atividades modernas (firmas citadas: Bung Borg, Sambra, Anderson Cleyton, Standard Brands, entre outras). Ressalve-se, no entanto, a referência, no mesmo tópico, ao cenário modernizador que se formara na economia açucareira quando, segundo o autor, sua produção passou a se dirigir ao mercado interno e o "capital comprador" fora eliminado. Advieram então "uma série de reformas burguesas, as quais encontram sua expressão legal no estatuto da lavoura canavieira (regulamentação das relações entre produtores de cana e usineiros, entre trabalhadores do campo e fabricantes do açúcar, limitação da renda da guerra, eliminação nos contratos de trabalho de algumas formas de prestação pessoal, etc." (idem). Neste caso, diz Passos Guimarães, a "penetração do capitalismo no campo" ocorre pela via "do reformismo, da conciliação com o feudalismo, cria mercado interno à custa da miséria da população rural trabalhadora" (idem). Ou seja, trata-se de um cenário em que uma economia feudal-estamental se moderniza sob feições "reformistas" (prussianas). O realce concedido ao "capital comprador", digamos assim, tem predomínio formal sobre as demais tensões determinantes do mundo rural. Mas também há indícios de que a referência daquele texto ao "capital comprador" não expressa simples apriorismo oriundo das duas revoluções chinesas, o autor limitando-se a revestir o modelo que esboçara em "Uma falsificação e vários erros crassos na questão das etapas" e inclusive em passagens do próprio "Três frentes da luta de classes no campo brasileiro", com o anti-imperialismo que moveria a revolução nas cidades e no mundo rural. ${ }^{57}$

Essas considerações revelam desníveis na construção de Alberto Passos Guimarães. Em "Três frentes da luta de classes no campo brasileiro", o autor abre o tema do "desenvolvimento capitalista no campo brasileiro" diretamente aludindo às vias farmer e prussiana. Neste e nos outros textos, faz as menções já citadas a traços prussianos em processos evolutivos da economia açucareira e do café. Aliás, o mesmo cenário do velho mundo dos engenhos volta em Quatro séculos de latifúndio com a descrição de um verdadeiro modelo. Passos Guimarães não sugere aí um quarto "tipo ideal" de latifúndio (ao lado dos engenhos, da fazenda de gado e da fazenda cafezista, desenhados com muitas linhas na monografia de 1963) conquanto o latifúndio já estava em declínio no tempo mais

\footnotetext{
${ }^{57}$ Registre-se, de passagem, que em Quatro séculos de latifúndio (no seu capítulo dedicado à controvérsia sobre o regime econômico da Colônia), o autor alude àquele cenário, como similar ao da antiga Prússia e do sul dos Estados Unidos (sic) onde o "monopólio feudal" existira em função do mercado interno. Ao permanecer retida a totalidade do excedente dentro do país, abrira-se a oportunidade para o latifúndio "modernizar-se gradualmente", "aburguesar-se, ou converter-se em grandes propriedades capitalistas" (Passos Guimarães, 1963; 1968: 36)
} 
contemporâneo dessas transformações. Em todo caso, em torno do exemplo da cana de açúcar o ensaísta retrata traços de uma evolução capitalista que seriam comuns a outros grandes domínios. ${ }^{58}$

\section{Considerações finais}

Por fim, façamos algumas considerações sobre esse texto propriamente dissertativo. Publicado em 1963, em tempo de teste do agrarismo comunista, Quatro séculos de latifúndio escapa ao objetivo destas notas concentradas na ocasião formulativa do V Congresso do PCB.

A monografia narra a trajetória do mundo rural desde um ponto de vista bem marcante, lembrando outros ensaístas das revoluções brasileiras, como Caio Prado em A revolução brasileira (1966), Florestan Fernandes em A revolução burguesa no Brasil (1975) e em certo sentido Gilberto Freyre em Ordem e Progresso (1959), cada qual com registro característico. O que justamente distingue Passos Guimarães é o leninismo que lhe vem da militância comunista. No ensaio de 1963, o ensaísta procura mostrar o papel renovador do campesinato em sentido construtivo, como Caio Prado, outro intelectual comunista que pressupõe o desenrolar "normal" dos acontecimentos no pré-64. Em Quatro séculos de latifúndio, ${ }^{59}$ Passos Guimarães confere centralidade à reforma agrária redistribuitivista por meio de uma dissertação sobre a gênese, a consolidação e o debilitamento e crises

\footnotetext{
${ }^{58}$ Em Quatro séculos de latifúndio, estes são os pontos com os quais o autor compõe tal modelo: 1) "Extrema concentração fundiária, baseada na associação do monopólio da terra ao monopólio da indústria de transformação ou do beneficiamento da matéria-prima agrícola"; 2) "A extrema fragmentação minifundiária das piores terras, por meio da qual os latifundiários fixam, nas suas adjacências, as reservas de mão de obra para atender as suas necessidades eventuais"; 3) "O abandono das lavouras latifundiárias e sua substituição, em larga escala, pela pecuária extensiva"; 4) "A introdução, ainda em ritmo lento e em proporções limitadas mas em escala crescente, de técnicas mais adiantadas de preparo e cultivo do solo, inclusive por meios químicos e mecânicos"; e 5) "A substituição, embora lenta, das formas pré-capitalistas de renda por formas semicapitalistas ou capitalistas; e a generalização, acelerada nos últimos anos, do salariado quase-capitalista ou capitalista." (Passos Guimarães, 1963;1968: 183-192).

${ }^{59}$ No acréscimo à segunda edição de Quatro séculos de latifúndio (1968), no novo capítulo 11 ("Depois de 1964"), Passos Guimarães continua se recusando a ver no avanço do capitalismo rural o esgotamento da reforma agrária. Inclusive procura ainda desqualificar as diretrizes e as ações modernizadoras do regime militar (Passos Guimarães, 1963; 1968).
}

dos grandes domínios; processo largo durante o qual também se firmaria o protagonismo camponês.

Lembrando o Manifesto do partido comunista, a monografia apresenta nosso mundo rural na sua trajetória de mundo polarizado por configurações antagônicas: de um lado, o sistema latifundiário e, de outro, os seus "intrusos e posseiros" dos séculos iniciais e a propriedade agrária capitalista, em época contemporânea. Invasores antigos e terceiro elemento que irão dar lugar às figuras da pequena e media propriedades. Renitentes, já os primeiros grupos de camponeses constituem, para Alberto Passos Guimarães, um "elemento dinâmico" renovador, cujas vicissitudes ainda estão aí na chamada agricultura familiar ao lado dos novos e pujantes grandes domínios de um mundo rural complexo e bem diferente destes nossos dias.

Para o interesse destas notas, realcemos que Quatro séculos de latifúndio reforça o agrarismo aprovado no V Congresso. Façamos um rápido apanhado do sentido de algumas passagens do livro: a) quando disserta sobre os primeiros três séculos, o autor deixa bem visível a marca da violência nos desvalidos que sobrevivem às margens da grande propriedade sob o império do “"governo' sobre as coisas e as pessoas" (noção extraída dos senhorios açucareiros vistos como o primeiro tipo-ideal da monografia); b) nas passagens relativas às brechas que se abrem à pequena propriedade, no século XIX, quando aquele sistema autocrático se fissura; processo já importante no primeiro ciclo imigratório e que adquire envergadura e estabilidade à sequiência da Abolição com a arregimentação dos "braços livres" para a grande lavoura sob novo ímpeto burguês e c) nas referências à época das crises cada vez mais crônicas que levam o sistema agrário à decomposição (este é um ponto importante dos capítulos de Quatro séculos de latifúndio referentes aos tempos do Império e inícios da República). No século XX, sobremaneira passada sua segunda metade, o autor alude a uma época de luta de classes diversificada que enseja um novo tipo de ação camponesa. Os grupos sociais se movem nas Ligas Camponesas e em suas articulações urbanas, movimentam-se largamente por meio dos sindicatos rurais. A "classe do passado" revela-se "elemento dinâmico" na reforma do mundo rural, quer pela importância que adquire a cada dia o seu "movimento social" - reivindicativo segundo Caio Prado e "movimento camponês", misto, como o chamam Alberto Passos Guimarães e outros, quer pela colocação da reforma agrária na vida nacional como um dos seus grandes temas. 
Em Quatro séculos de latifúndio Alberto Passos Guimarães releva tanto a debilidade da "classe mais numerosa da nação" como the vê possibilidades de crescimento conforme seus mediadores aproveitem as oportunidades políticas do contexto de declínio do latifúndio e de crescente democratização do país. Contexto que se afirma à medida que o mundo político se diversifica potenciando nas mediações existentes - eleições, partidos, associativismos e opinião pública - posturas que abrem caminho, inclusive na esfera de governo (incentivo à sindicalização, Estatuto do Trabalhador Rural, a desapropriação às margens das rodovias federais, etc.). A narrativa de Passos Guimarães não antevê uma relação entre economia e sociedade - pré-determinada por razões doutrinárias - de estímulo natural à organização camponesa. A afirmação de um terreno no qual a luta de classes cada vez mais tivesse curso livre exigia a ação consciente e política dos protagonistas. Não constitui acaso que para resgatar o papel dos camponeses na história brasileira, Alberto Passos Guimarães sublinhe a pouca autonomia dos agrários, referindo-se "à necessidade da quebra do 'governo' sobre as coisas e as pessoas" e sua associação com o chamado campo democrático reformista da época.

Mesmo que em seus textos congressuais não tenha como principal visor a hipótese prussiana, Passos Guimarães exibe a questão agrária em uma circunstância particularizada por qualificações que reaparecem na monografia: a) quando nos capítulos dedicados à época colonial o autor disserta sobre a "civilização portuguesa" que aqui não constrói o novo a partir do traço mais moderno - à época, o mercantilismo - mas viria sedimentar, com instituições pretéritas, a grande propriedade em moldes estamentais. É em tal mundo que os desvalidos rurais emergem, numa relação invertida, comparada nossa circunstância com a via clássica dos enclousures: os camponeses brasileiros surgem, depois de constituído o grande domínio territorial, sob condições de subordinação e tutela profundamente arraigadas; e b) quando disserta sobre o período contemporâneo, o autor mostra um mundo agrário marcado por crises; com o passar dos tempos, mais enfraquecido e diferenciado (estes temas do debilitamento, fratura nos de cima e diferenciação social percorrem o volume conformando contexto político progressivamente favorável à movimentação dos desvalidos). Embora tal mundo rural, sem ter o fechamento dos antigos grandes domínios, continue recriando constrangimentos tanto ao trabalho quanto ao ambiente político-cultural em que vive um cidadão rural livre há mais de um século.

Salvo revisão mais cuidadosa, dir-se-ia que Alberto Passos Guimarães não perpassa as dimensões do "movimento camponês" com a abertura que lhe propicia a hipótese prussiana, daí extraindo todas suas consequências. Quando enfatiza o monopólio da terra e os "restos" que este arrasta do pretérito, o autor está próximo do conceito leniniano, mas não se pode desprezar que é com a noção do "capital comprador" que Alberto Passos Guimarães hierarquiza as determinações do mundo rural. É visível seu empenho em pôr em primeiro plano o "fator nacional no campo", em um certo sentido lembrando a José de Souza Martins. ${ }^{60}$ Em busca do protagonismo camponês, Martins, digamos, correndo o risco da simplificação, estrutura toda, ou quase toda, sua construção - também mobiliza de modo importante os temas das temporalidades coetâneas (Henri Lefebvre) e da cultura - na relação capital-trabalho (como Marx apresenta o tema no famoso livro, volume primeiro). Como consequência do processo de sua territorialização, o capital descrito por Marx passa a subsumir, no tempo mais contemporâneo, cada vez mais importantes dimensões do mundo rural brasileiro. Embora o sociólogo procure decifrar o sistema produtivo agrário com um suporte (academicamente elaborado) que em larga medida o diferencia do comunista, ambos autores - neste ponto em que Alberto Passos Guimarães recorre ao "capital comprador" - compartilham uma busca campesinista tendo por pano de fundo forte recurso a categorias abstratas. Martins amplia aquela sua referência a Marx associando o anticapitalismo camponês ao nexo capital-renda da terra (recoberto pelo registro da história lenta e o tema da cultura popular-familística). Por sua vez, na sua referência ao "capital comprador" Passos Guimarães como que abstrai a ideia de revolução na periferia capitalista com que pensara o início não camponês da revolução agrária, deixando subentendido estarmos numa circunstância colonial stricto sensu. Embora, doutra parte, tenha sublinhado no tema camponês a dimensão da política entendida nos termos da diretriz da "frente única permanente" do seu partido.

${ }^{60}$ Em outra oportunidade - quando compararmos o campo comunista com a matriz alternativa que enseja a interpelação camponesa mais contemporânea -, voltaremos àquela ideia da proximidade entre autores tão diferentes. Quatro séculos de latifúndio (1963) e Os camponeses e a política no Brasil, no seu primeiro ensaio (Martins, 1980; 1981) são textos que se singularizam por um grande empenho em valorizar o protagonismo camponês. 
Como ocorre com Caio Prado, autor comunista que exibe várias aporias, a argumentação de Alberto Passos Guimarães carrega ambiguidades não poucas vezes revestidas de muita doutrina. Do mesmo modo que a indagação sobre as variações advertidas em textos de outros clássicos desperta curiosidade, como é o caso do redimensionamento do paradigma revolucionário em um acadêmico rigoroso como Florestan no livro de 1975, perquirir a respeito de certas passagens da publicística de Alberto Passos Guimarães tem interesse pois permite avaliar até que ponto elas enfraquecem pontos seminais de um autor que buscou uma variante brasileira de "revolução nacional" em meio a fortes modelos marxistaleninistas nos quais o seu PCB vivia imerso.

\section{Referências bibliográficas}

CHAVES NETO, Elias. Política de união nacional. Revista Brasiliense, n. 1, São Paulo, setembro-outubro de 1955. 1977.

Minha vida e as lutas do meu tempo. São Paulo: Alfa-Omega,

COELHO, Marco Antonio (Assis Tavares). A tática das soluções positivas. Novos Rumos, São Paulo, 19 de julho a 4 de agosto de 1960.

ENGELS, F. Crítica al programa de Erfurt (1891), Madri: Anagrama, 1973.

. Introdução a As lutas de classe na França de 1848 a 1850 (1895). In: C. Marx e F. Engels, Obras escojidas. Moscou: 1977.

O problema camponês na Franca e na Alemanha (1894). In: $A$ questão agrária, São Paulo: Brasiliense, 1981.

FREYRE, Gilberto. Ordem e progresso. Rio de Janeiro: José Olympio Editor, 1959.

KONDER, Leandro. A democracia e os comunistas no Brasil. São Paulo: Graal, 1980.

LÊNIN, W. I. Qué hacer. (1902). In: Obras escojidas en doze volumes, v. 1, Moscou: Editorial Progreso, 1975.
Dos tácticas de la social-democracia rusa (1905). In: Obras escojidas en doze volumes, v. 1, Moscou: Editorial Progreso, 1975.

El programa agrário de la socialdemocracia rusa (1907). In: Moscou: Editorial Lenguas Extranjeras, 1949.

MARÇAL Brandão, Gildo. Partido comunista, capitalismo e democracia, São Paulo: USP, 1992. Tese.

MARTINS, José de Souza. Os camponeses e a política no Brasil. Petrópolis: Vozes, 1981

MOORE JR., Barrington. As origens sociais da ditadura e da democracia. Senhores e camponeses na construção do mundo moderno. Lisboa: Martins Fontes, 1983.

PASSOS GUIMARÃES, Alberto. A questão das etapas da revolução brasileira. Novos Rumos, Rio de Janeiro, 8 a 14 de julho de 1960a.

Uma falsificação e vários erros crassos na questão das etapas. Novos Rumos, Rio de Janeiro, 22 a 28 de julho de 1960b.

As três frentes da luta de classes no campo brasileiro. Novos Rumos, Rio de Janeiro, 28 de julho a 4 de agosto de 1960c.

Quatro séculos de latifúndio (1ª . ed., 1963). Rio de Janeiro: Paz e Terra, 1968. PCB. Declaração sobre a política do PCB (março de 1958). In: Carone: $O P C B$, vol. II, São Paulo: Difel, 1982. 1960

Teses para o V Congresso do PCB, Rio de Janeiro, folheto,

Informe de balanço do comitê central ao VI congresso do PCB (1967a). In: Vinte anos de política. Documentos. São Paulo: Lech, 1980.

PRADO JR., Caio. Formação do Brasil contemporâneo. São Paulo: Livraria Martins Fontes, 1942.

História econômica do Brasil. São Paulo: Brasiliense, 1945.

Os fundamentos econômicos da revolução brasileira. A classe operária, São Paulo, 1947.

A revolução brasileira. São Paulo: Brasiliense, 1966. 
RIBEIRO, Ivan. A agricultura e o capitalismo no Brasil (1975). Originariamente em Études Brasiliennes (Paris, s/d). In: Presença, n. 11, Rio de Janeiro, 1988.

SANTOS, Raimundo. Questão agrária e política: autores pecebista, Seropédica: EDUR, 1996.

- Política e agrarismo sindical no PCB, Brasília: Fundação Astrojildo Pereira, 2002.

SODRÉ, Nelson Werneck. Formação histórica do Brasil. São Paulo: Brasiliense, 1962.

STALIN, José. Cuestiones del leninismo. Moscou: eds. Lenguas Estranjeras, 1949.

VIANNA. Luiz Werneck. Liberalismo e sindicato no Brasil. Rio de Janeiro: Paz e Terra, 1976.

. Sobre a tática e a estratégia das Teses. Voz da Unidade, Debate n. 89, São Paulo, 1981.

VÁSQUEZ, Adolfo Sánchez. Ciencia y revolución (el marxismo de Althusser). Madrid: Alianza Editorial, 1978. 